\title{
ラット切歯のエナメル質形成に及ほす薬荗の影響
}

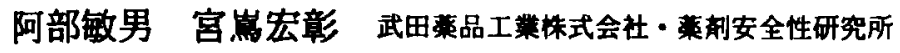

\section{EFFECT OF DRUGS ON DEVELOPING ENAMEL IN RAT INCISORS}

Toshio Abe and Hiroaki Miyajima Drug Safety Research Laboratories. Takeda Chemical Industries, Ltd.

\begin{abstract}
The basic structure of rat incisors and the process of enamel formation are reviewed, and the drug-induced lesions of rat incisors are discribed.

The rodent incisors grow, calcify and erupt continuously throughout the life of the animal, and show in one longitudinal section the complete life cycle of tooth development from inception to maturity. Therefore it is a valuable biologic indicator which reflects and records. during its development, the metabolic status of the animal. Drug-induced lesions in developing enamel of incisors are white discoloration of enamel surface, degeneration, necrosis, and atrophy of ameloblasts and/or papillary cells. disturbance of pigmentation, and hypocalcification of enamel. These changes correlate with the stage of enamel formation. The advantage of using rat incisors for toxicity studies is stressed. (J Toxicol Pathol 3: $245 \sim 256,1990$ )

Rey words: Rat incisors. Biologic indicator, Enamel, Ameloblasts, Drug-induced lesions, Disturbance of pigmentation
\end{abstract}

\section{籍 䡒}

歯牙は生体を構成する重要な器官の一つである が, 哺乳類では成長に伴って分化が終了し，肝㳚

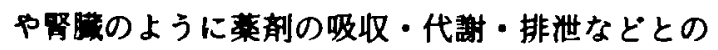
直接的な関連性が少ないことから毒性学的にはあ まり重視されてこなかった。しかし、ラットやマ ウスのような䟧菊目の切歯は生体内でもっとも旺 盛に成長し綍ける器官の一つであり，苏戍の投与 によって䅈牙の形成が阻害された場合は，おる日 数を経過した後に器筫的変化として外見上からも 明確に識別されることがある。したがって，海牙 は莧骶の影需を retrospectiveに知る上で重要な情 報を提供する biological indicator でり，毒性学 的な意義は大きいと考えられる。

本稿では，筆者らの経験例を中心に，薬绪投与 による切菌のエナメル筫形成過程における病理形

Accepted for publication: August 1, 1990 Mailing address : Toshio Abe, Drug Safety Research Laboratories, Takeda Chemical Industries, Led., 6-10-1, Himurocho, Takatsuki, Osaka, 569, Japan.
䈍学的変化ならひに発生病理に関する考察を報告 する。菌牙の形成障害を理解し易くするため，は じめに歯牙の基本㩐造, ラットにおける切苗の基 本棈造およびエナメル質の形成過程について概説 し，次いでラット切歯のエナメル貿形成における 毒性病理について論述する。

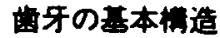

菌牙は鳥類以外のすべての准㽖物にみられ， いずれもエナメル質 (enamel)，象牙質 (dentin)お よびセメント䨘 (cementum) の三つの硬組織と㧘 觬などから楼成されている。エナメル質は外肧葉 由来のエナメル芽細胞 (ameloblast)によって形成 され，最も石灰化度が高い組織で，約 95\%の無機 成分を含んでいる'。象牙質およびセメント質はそ れぞれ中肧葉由来の象牙芽細胞 (odontoblast) お よびセメント芽細胞 (cementoblast)によって形成 され，骨と類似の組成でそれぞれ約 $65 \%$ およ゙゙ 45\%の無機成分を含み，膠原線維を主体とした有 機貿と水分から構成される1。このように主要な石 灰組織がエナメル芽細胞, 象牙芽細胞およびセメ 
ント芽細胞という発生由来を異にする 3 種類の細 胞群によって形成されるところに菌牙の特徵があ る。

\section{ラット切遗の基本得造（図 $1,2 ）$}

ラットやマウスのような豐藏目およびウサギの ような重菌目は、ノミのようにするどい切菌を 上・下額にそれそれ一対もっている。これらの切 歯は、根尖部にある齿胚の細胞の分裂增殖によっ て終生成長し続けることから，常生歯 (continuously growing tooth) あるいは無根菌 (rootless tooth) と呼ばれている゚。側はエナメル芽紐胞,

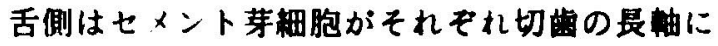

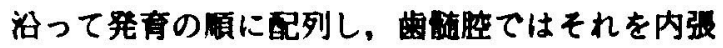
クして象牙芽耦胞が列列している。エナメル芽細 胞は有機性基曾を分泌し，解買船送によって，石 灰化を行いながらエナメル面を形成し，やがて基 貫を脱却してエナメル貫の成熟を促進する゙。この ようにエナメル貫の形成過程においては，いった ん分祕された基貫が石戻化の進行とともに脱却さ れ，最終的にその基筫の占めていた空間がハイド ロキシアパタイトを主成分とする鉱質によって占 められるようになる。そのため石灰化したエナメ ル筫は病理標本作憋の際の脱戻操作によって溶失 してしまう。象牙芽細胞およびメメン芽細胞は それそれれ有機性基質を分论し，電解質渝送を行っ て石灰化を促進し，象牙䁈およびメント貝を形 成する。しかし，象牙寊の石灰化においては，エ

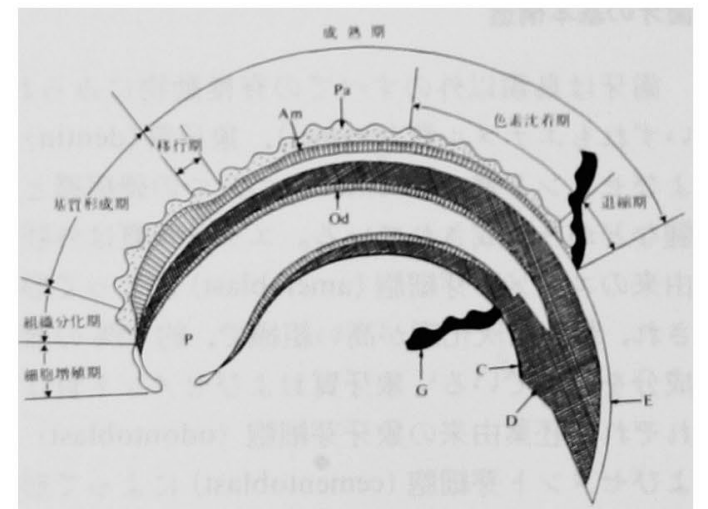

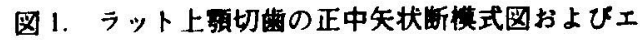
ナメル筫の形成遇程

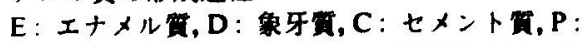

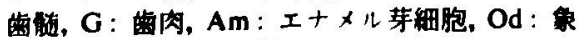
牙芽細胞, $\mathrm{Pa}$ : 叛頭屋

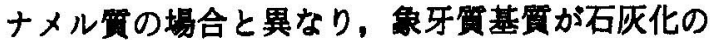
進行に伴って脱却されるという被﨎な過程は存在 しない。いすれれしても，これらの芽細胞は歯留 を形成しながらエスカレーター式に切雪端に向 かって移動する。歯の萌出あるいは長軸的移助を 起こす要因としては，齿顝あるいは菌周囲組織内 に発生する液圧あるいは線維芽細胞によって荤引 力が発生するという説が有力視されている゙。萌出 した切歯端は啧み合わせによって磨耗し，切歯の 舆さはほほ一定に保たれる。一側の切歯を切断し た埸合には対側の切蒾の萌出速度は增加する゙。 ラットの切雷は一週間に上䁰で $2.1 \mathrm{~mm}$, 下硕で $2.8 \mathrm{~mm}$ の割合で萠出し，40日から50日で全て生 え代わる。。筆者らの判定ては，10週龄のF344 ラットの切虚の萠出速度は佴の形状にあまり成係 が無く，一週間に上顆て約 $3 \mathrm{~mm}$, 下影で約 $4 \mathrm{~mm}$ てあった。ラット切雪ては生後 10〜12 日踣から色 亲沈著が開始され7, 加龄とともに切齿の表面は裸 色調を星するようになる。上碩切㐘においては、下 䫫切崡に比较して切歯表面の褐色調が流くみられ るが，それは後述するエナメル質形成過程におけ る色来汁着期が長いことと閏連する。

\section{ラットにおける切慻エナメル需の形成迥程}

前述のようにラットの切畨は常生菌であり，一 本の微断面でエナメル筫形成の全過程を同時に観 察することがてきる。エナメル䨘は上・下影切歯 ともに唇側を占め,エナメル舟細胞によって形成 されるが，その過程の分類は人によってさまさま である゚-12。本稿では比较的汎用されている須賀

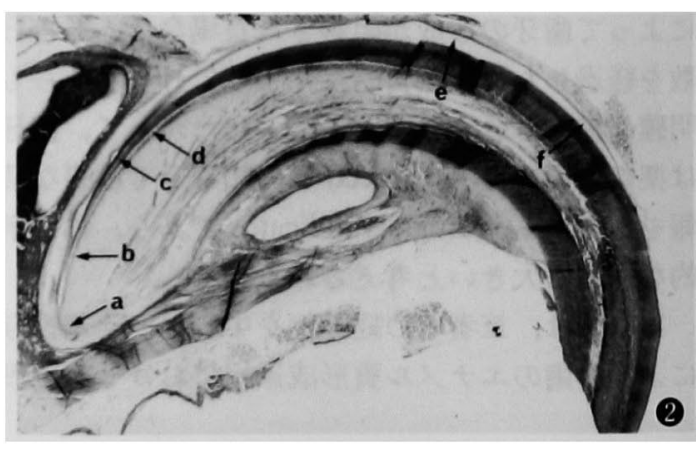

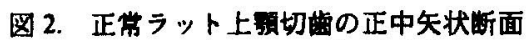

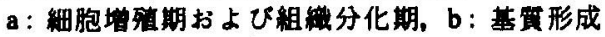

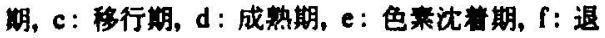
樎期. H.E., $\times 5.2$ 
の分類に㳯じてエナメル賈の形成過程を以下の 4 stage に分類する。

1) 倜胞场要期 (stage of cell proliferation) (国 3) 根尖部にある怔の上皮性細胞が分裂，增殖す る時期て，エナメル芽細胞に分化する内エナメル 上皮細胞および後に乳頭单を形成する中間首細 胞，エナメル值細胞および外エナメル上皮細胞が 出現する。

2）相穜分化期 (stage of histodifferentiation)（因 3) エナメル基賽の分泌は象牙買の形成より少し遇 れて始まるが、この象牙實の形成開始からエナメ ル基貫の分泌が始まるまての時期を指す。この時 期には内エナメル上皮湅胞における細胞内小器官 の分化が進行する。

3) 基筫形成胡 (stage of matrix formation) (图 4) エナメル芽湅胞がエナメル基嘪を形成する時期 を指す。エナメル基實はアメロゲニンやエナメリ ンなどのエナメル蛋白からなっており，高度な石 欧化を示さず, 酸不溶性てある13。エナメル芽細胞 は高さ的 60〜 70 $\mu \mathrm{m}$ の高円柱状て, 基底側細胞質 には1〜2 個の核小体をもつ棈円形の核が偏在し ている。また，すへての核が同位置に並列してい ろのてはなく，少しずつ高さを異にして眍列する 㑯向をもっている。この時期のエナメル芽細胞に は先端部に突起の形成 (Tomes の突起) がみられ, 電影的には典型的な蛋白分泌型の細胞形隹を備え ている14。エナメル芽細胞の基底側には扁平な中 間届細胞，その外側に広い細胞間隚をもった星状 のエナメル铕細胞, さらにその外側には不整立方 形の外エナメル上皮細胞があり，それが周囲の結 合組織に接している。これらの細胞の機能的役割 はよくかかっていないが， ${ }^{125} 1$ 摆誠血清アルプ ンの分布梂式から，血液とエナメル基賈の間の「血 液一エナメル基貿閶 (blood-enamel matrix barrier)」の形成に関与している可能性がある ${ }^{15}$ 。

4) 成整期 (stage of maturation) (图 5〜8)

エナメル基貫の形成が終了してから萌出するま ての時期を指す。この時期においてエナメル芽細 胞やエナメル基質の機能と形状が劇的に変化す る。これらの変化は，初期におけるエナメル芽細 胞の形䈍変化（高円柱状，立方状）に始まり，工 ナメル蛋白の脱却とそれに伴う石灰化度の上昇な らぴにエナメル質における石灰化の完了，鉄色菜
の沈着 (色羔沈着期)，エナメル芽細胞の退縮（退 縮期）と続く。成熟期の初期においてエナメル牙 細胞は高円柱状から, 短小化して立方状の形態に 移行し，その形態的な特徵からこの時期を移行期 と呼ふ（図 5)。移行期において約 25\%のエナメル 芽細胞は変性・壤死を星し、これらは中間層細胞 あるいはマクロファージによって処理され $3^{18,17}$ 。成热期に入ってから後, エナメル芽細胞の 退縮が始まるまての期間，エナメル芽細胞は細胞 實の基觉側末端に刷子緑をもつ時期 (ruffle-ended ameloblasts : RA) と，もたない時期 (smoothended ameloblasts : SA) を交互に 3 4 回くり返 しながら変化する。これはエナメル䨘の有機性基 買脱却の他に，ミネラルの添加をはじめとするエ ナメル面成蒴化のための諸機能と密接に関連した 形腎変化と考えられている12.18。色素沈着期(図 7) にはエナメル芽細胞の胞体内に鉄反応隔性の色亲 顆粒が出現し，この色素顆粒は次第にエナメル質 表眉へと移行沈着する。切菌の表面か裸色調を示 すのはこの鉄色等に由来する。鉄色素はトランス フェリンを介して血清中の鉄イオンがエナメル芽 細胞に渝送されて形成されたもので，前述した刷 子縁をもつ時期のエナメル芽䋥胞 (RA)にはトラ ンスフェリンのレセプターが多く分布してい る19。色素沈着期を経過するとエナメル芽細胞は 次第に退樎する（図 8)。このようにして形成され た切雪の先端部はやかて萌出し，嘴み合わせに よって切雪端から唐耗消失する。前述した中間首 細胞, エナメル随細胞および外エナメル上皮細胞 は成熟期に入ると，形態と配列を変えて乳頭層を 形成し、その間に毛細血管が介在するようになる。

\section{エナメル筧形成障客の望性病理}

笔者らは各種の薬剤による毒性試験の際に， ラット切歯に白色変色巣（白色化）が発現するこ とに注目し、これらの変化が肉眼的には類似して いるにもかかわらず病理組織学的には病変が多様 であることを経験した。そこでエナメル質形成過 程において，最初に病理組織学的変化が発現する 時期を指標に切㐘の障害を以下の 4 種類のタイプ に分類した。

1. 基質形成期に始まるエナメル芽細胞の障害

2. 移行期に始まるエナメル芽細胞の障害 


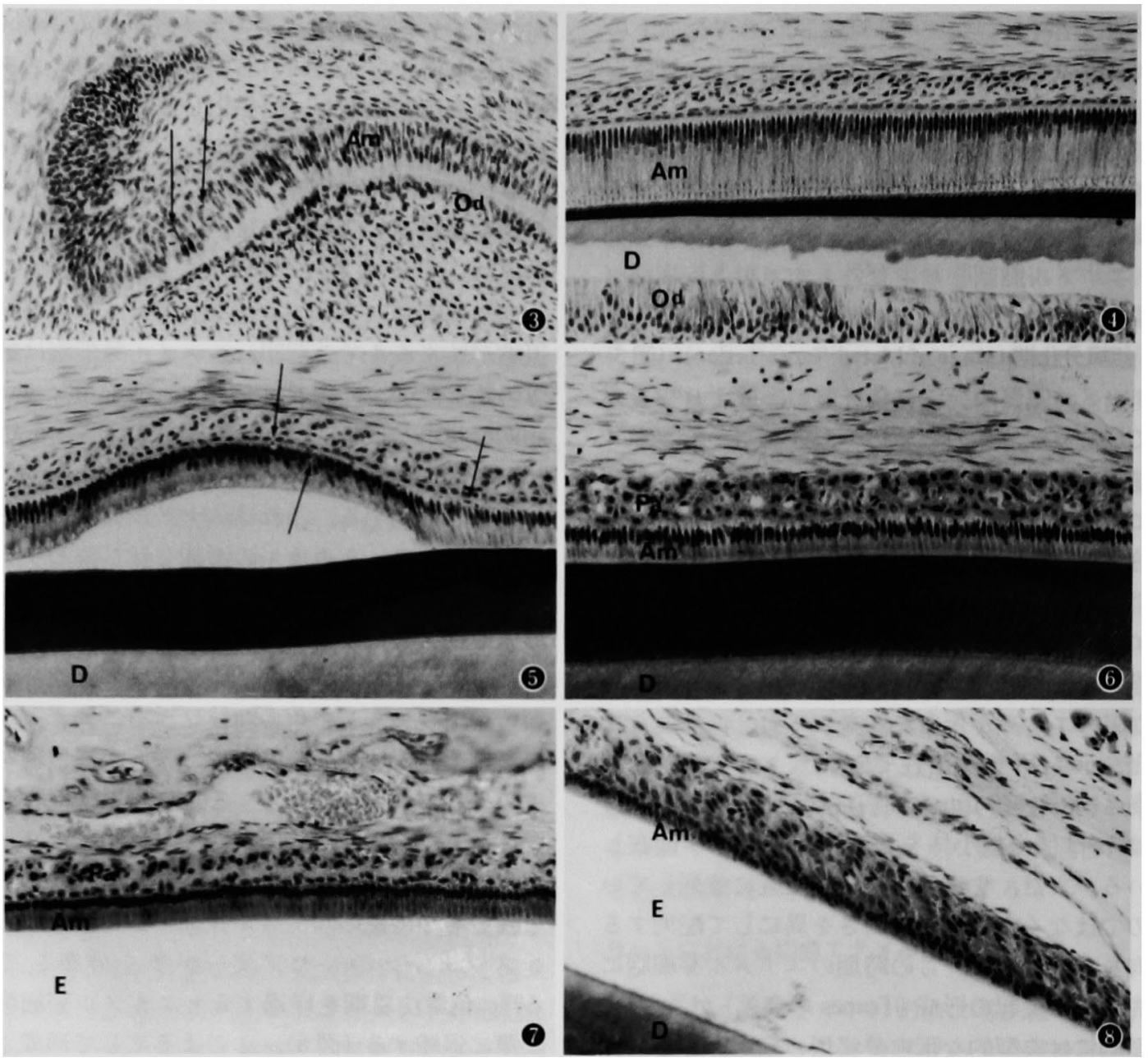

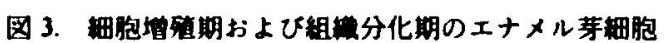

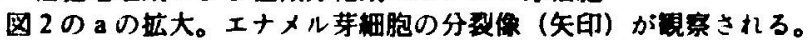

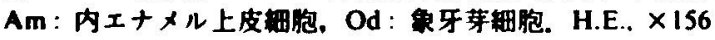

図 4. 基曾形成期のエナメル芽細胞

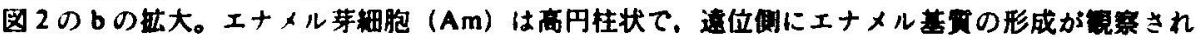

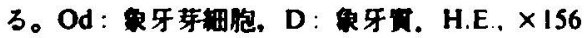

因 5. 楼行期のエナメル舟細胞

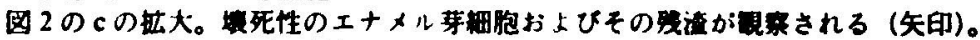

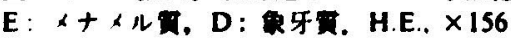

因 6. 成然期のエナメル第用胞

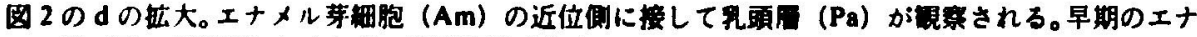

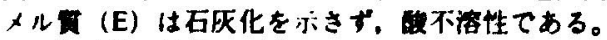

D : 牙军. H.E., $\times 156$

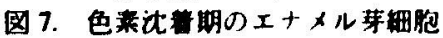

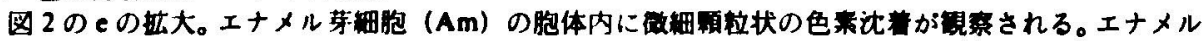

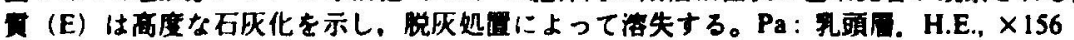

因 8. 䢙編期のエナメル芽解胞

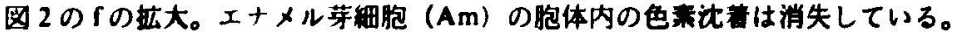

E：エナメル赛，D：象牙页. H.E., × 156 


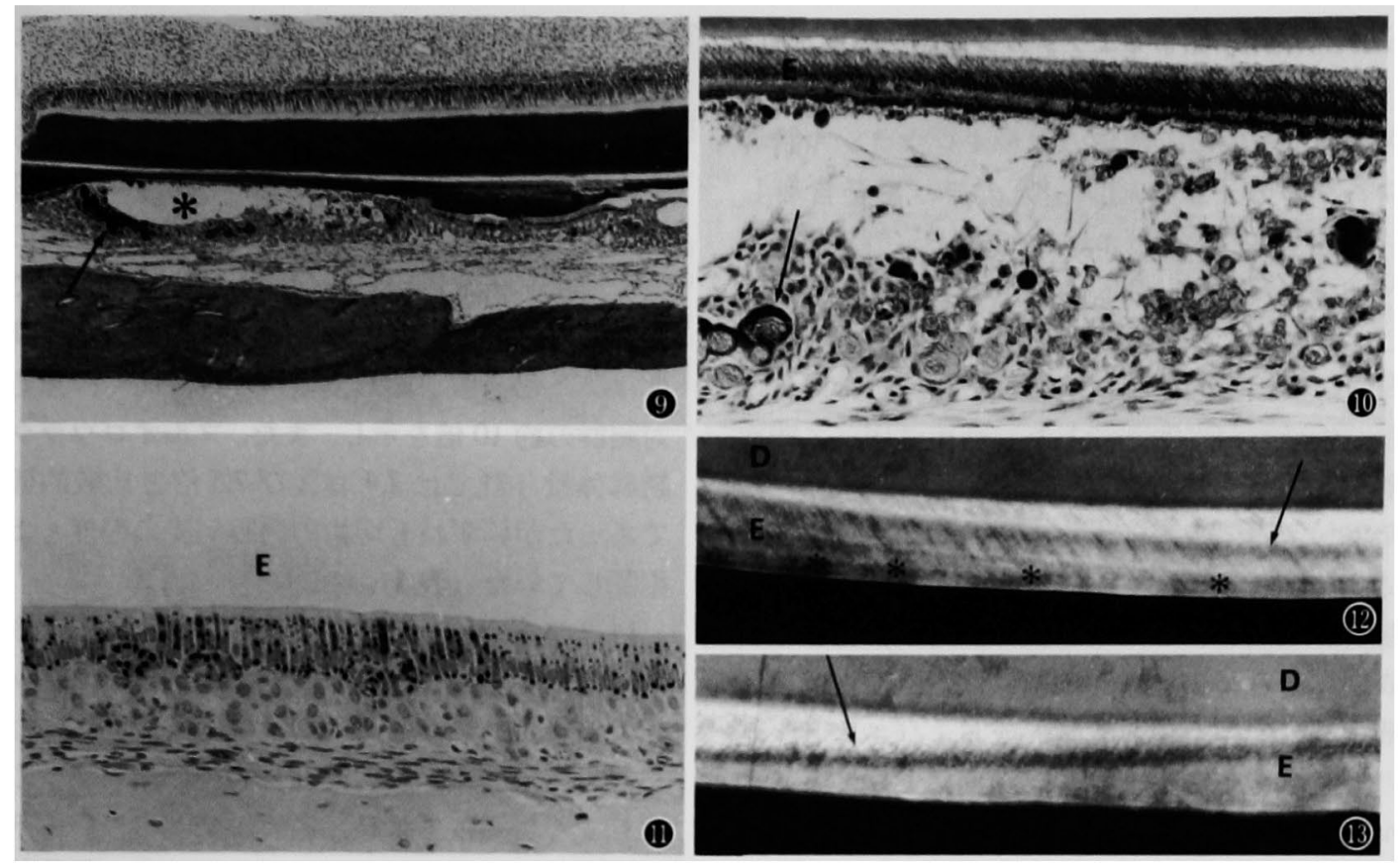

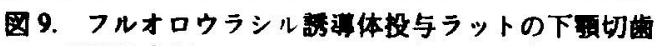

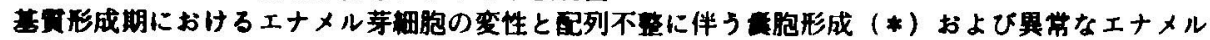
基實 (知) を示す。D：象牙贯. H.E.. ×32

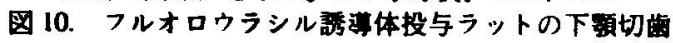

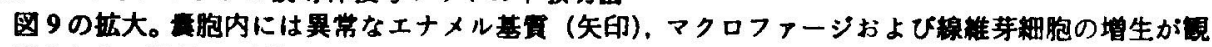
察される。H.E., $\times 156$

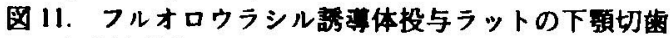

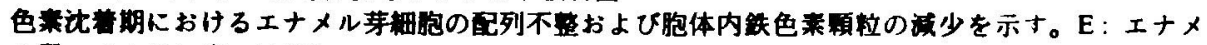
ル面. ベルリン青. $\times 156$

図 12. フルオロウラシル新䒩体投与ラットの下預切齿 エナメル䨘における石反化不全線（知印）およひ石灰化不全帯（）を示す。

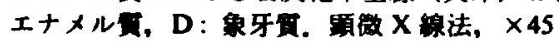

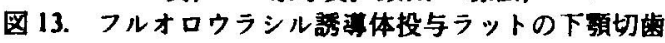

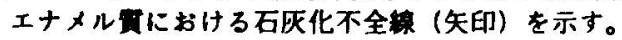

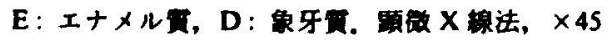

3.色采沈着期に始まるエナメル芽細胞および 乳頭展細胞の障害

4. 基貿形成期〜退缩期のエナメル芽細胞の障 害

\section{検来方法}

投萝を終了した動物は，エーテル麻醉下で腹部 大動脈より採血し，剖検した。摘出した上額およ ひ下預切菌は, 周囲の筋肉組織を取り除いた後に, 骨組織を軽く研磨して菌髄を露出させ，10\% 中性 䋓衡ホルマリン液に固定した。

病理組織学的検査には，切歯をEDTA-4Na あ るいはトリクロール酢酸で脱灰し，パラフィンあ るいはセロイジン・パラフィン二重包埋の後, 薄
切し, ヘマトキシリン・エオジン(H.E)，アザン・ マロリー,ベルリン青およびアルシアンフルー・ PASの各染色を行った。顕微 X 線法(マイクロラ ジオクラフィー)による観察には，切霜をポリエ

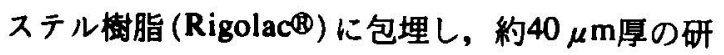
磨標本を作製した後, Softex®(日本ソフテックス 社, CMR型) でContact microradiogram ( $7 \mathrm{Kv}, 3$ mA, 10〜30 min.) を撮影した ${ }^{20.21 。}$

切㐘中のフッ素灌度の化学的測定には下䫑切歯 を微粉化した後, Lanthan-Alizarin Complexon methodで測定した。 


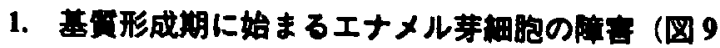 13)}

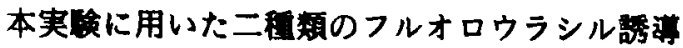
体は各々の分子年の約 7 8\%のフッ秦を含有し ている。それらの $200 \mathrm{mg} / \mathrm{kg} /$ day および $500 \mathrm{mg} /$ kg/day を 4 週齡の雌ラットに 8 週間経口投与す

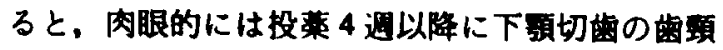
部表面に横繶状の白色策が吐現した。この变化は

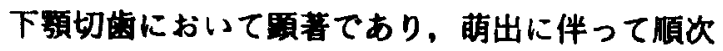
移動するとともに齿頚部付近からは新たな白色紧 が発現し切歯の表面全体に広がった。病理組醉学 的には，エナメル貫形成過程における最初の変化 が基實形成期エナメル芽蜔胞に認められた。基票 形成期にあるエナメル芽細胞には空胞変性，晨死。

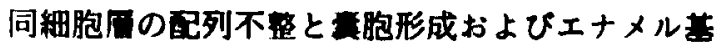
䨘の異常な産生がみられ，成然期においてもエナ メル芽湅胞の国列不整が認められた。色来沈著期

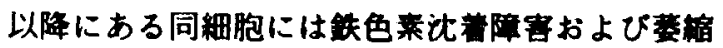
が䏸められた。このようなエナメル芽細胞の变化 は基實形成期に障害を受けたエナメル芽細胞が色 来沈着期に至っても传復せずに存在していること

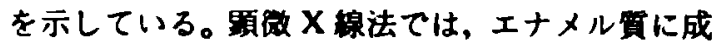
長線と一致して斜めに走ろ線状の低石灰化，いわ 四る石灰化不全線 (Calcio-traumatic line) およひ エナメル質表居からエナメル・象牙兵の境に向か う帯状あるいは巣状の低石灰化，いわゆる石灰化 不全帯 (Calcio-traumatic zone) がみられた。これ らエナメル質における低石欧化の発現様式 22 ら，石灰化不全線は基算形成期エナメル芽細胞の 障害に，また，石灰化不全带は成晟期エナメル芽 細胞の障害に起因すると考えられる。

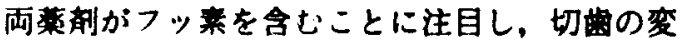

化と切茜に含まれるフッ来濃度との咸連性につい て湌时した。フッ化ナトリウム（NaF）および両 薬都を，いずれもフッ亲 (F) 換算て等五になるよ うに調整し，4週龄の雌ラットに8 週間経口投与 した。その結果，各投与群には肉眼的な切蔽の白 色変色巣が発現し、フッ化ナトリウム投与群ては その変化が最も強く舅められた。切菌のフッ素湿 度はフッ化ナトリウム投与群で最も高く，無処置 対照群の約 10 倍を示し, また,フルオロウラシル 誘等体投与群ては 2.4 および 7.5 倍と比较的低值 であったがいずれも切宷の肉眼病変の程度とよく 相阅していた（竞 1)。

以上の病理租学的模亘および䫏微 X 線法て みられた病変および発現時期は、ラットのフッ亲 症で報告されている切齿の変化に類似していた。 また，切齔中のフッ来灌度と切歯の肉眼病変の程 度もよく相䦎しており，病変の発現には両薬用に 含まれるフッ来の间与が示唆された ${ }^{28}$ 。両藥詴投 与ラットにおいて梱胞增殖期および細胞分化期の エナメル芽細胞に異常が認められないことから， 切菌の変化は休莱に伴って切增端へと移娌し，順 次正常の組緯に置されると考えられる。

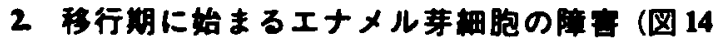
17)

ある㻎のマクロライド系抗生物貝の大量（5000 $\mathrm{mg} / \mathrm{kg} /$ day) を 4 週鈴の㠛雄ラットに 5 週間释口 投与すると，肉眼的には投莫 4 週以降に上碩およ び下碩切齿の表面に周期性をもった带状あるいは 不規則な棤絽状の白色変色紧がみられ，とくに下 額切齿における出現頻度が高かった。病理組織学 的には，エナメル貫形成過程における最初の変化 が移行期エナメル芽細胞に認められた。この時期

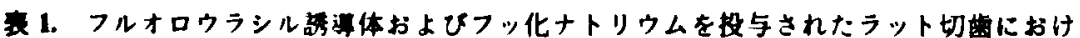

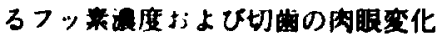

\begin{tabular}{|c|c|c|c|c|c|}
\hline 化 & 合 & 物 & & フッ素湍度 (ppm) & 肉眼要化 \\
\hline \multicolumn{3}{|l|}{ 無処四 } & $(5)$ & $60.0 \pm 13.3^{b}$ & - \\
\hline \multicolumn{2}{|c|}{ フルオロウラシル誨珼体 } & $\mathbf{A}$ & $(5)$ & $146.6 \pm 17.2^{\circ \bullet}$ & + \\
\hline \multicolumn{2}{|c|}{ フルオロウラシル新覃体 } & B & (5) & $453.2 \pm 57.9^{\circ *}$ & H \\
\hline \multicolumn{3}{|c|}{ フッ化ナトリゥム } & (5) & $604.6 \pm 37.9^{\cdots}$ & $H \sim \#$ \\
\hline
\end{tabular}

: Number of rats. : Mean \pm S.D.

* : Significantly different from control, $\mathrm{p}<0.01$

Grading of discoloration: -, none; +slight; \#, moderate; $\#$, severe. 


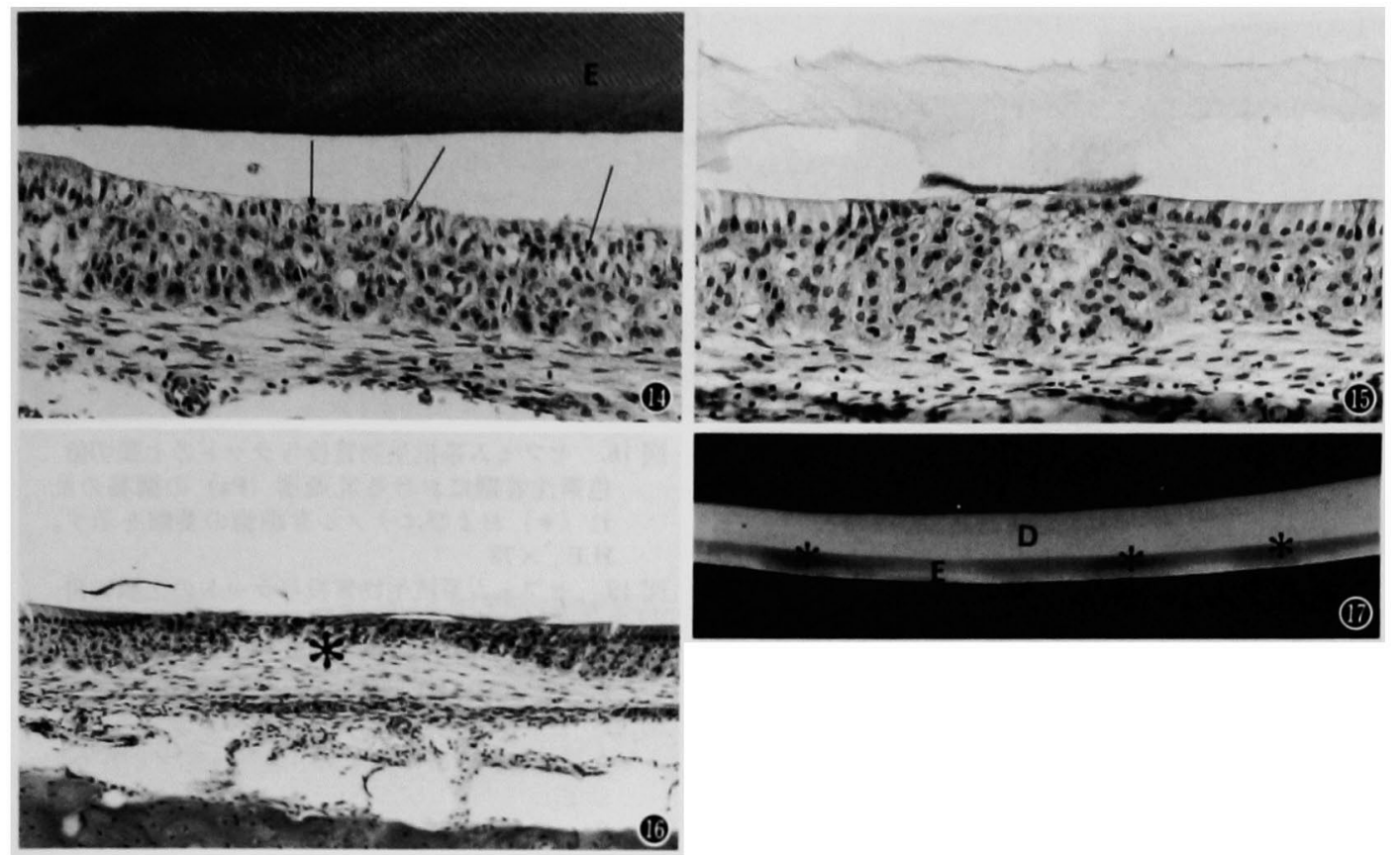

图 14. マクロライド系抗生物两投与ラットの下到切贯

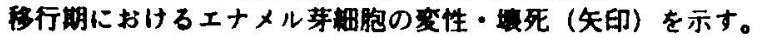

E: エナメル西, H.E., $\times 156$

图 15. マクロライド采抗生物页投与ラットの下预切庭

成整期エナメル芽料胞の変性およU゙列不整を示す。H.E., × 156

图 16. マクロライド系抗生物寊投与ラットの下预切菌

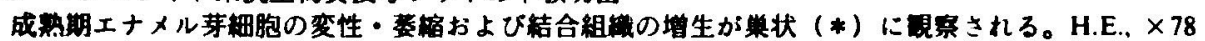

図 17. マクロライド系抗生物贯投与ラットの下碩切商

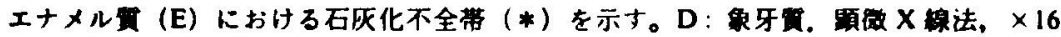

において变性・壤死を示すエナメル芽細胞が多発 し，これに続く成熟期においてはエナメル芽細胞 の空胞変性，燷死がみられた。変性したエナメル 芽㪴胞に接する部位には脱灰によって溶出すへき

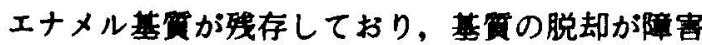
されていることを示していた。また，エナメル芽

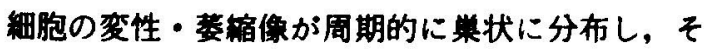
の直下の乳頭居領域には結合組織の增生が認めら れた。色来沈着期において変性あるいは変形に 陷ったエナメル芽細胞の胞体内には鉄反応隔性の 顆粒が異常に充满し，鉄色素の分泌障害を示して いた。影微 X 線法では，エナメル筫の表厢部に石 乍化不全帯が周期的に認められた。休蓧 9 週後に は切整の肉眼的変化は萌出に伴い消失し, 変化の 再発は認められなかった。

移行期におけるエナメル芽細胞は基質形成期か ら成唯期への機能変化に対応して, 微細形態学的
には細胞内小器官の再檄成が行われ, 短小化す ろ24。この時期において同細胞の壤死が多発して みられることは，成熟期エナメル来細胞への機能 および形䈍転換の障害が生じたものと推察され る。エナメル買の周期的な石灰化不全帯は成筑期 エナメル牙練胞の変性・萎縮像に対応した所見で あり，エナメル基貿の脱却および石灰化の障害を 示す所見と考えられる。また，エナメル芽細胞の 変性・菱縮像が周期的に䉓状に発現することから， 成热期エナメル芽細胞が薬绪投与の影響を一様に 被るのではなく，高感受性を持つ特定の細胞群の 存在することが考えられる。この細胞群が刷子緑 のある細胞 (RA)あるいは刷子縁のない細胞 (SA) のいずれかの可能性が考えられるが，詳細は不明 である。 


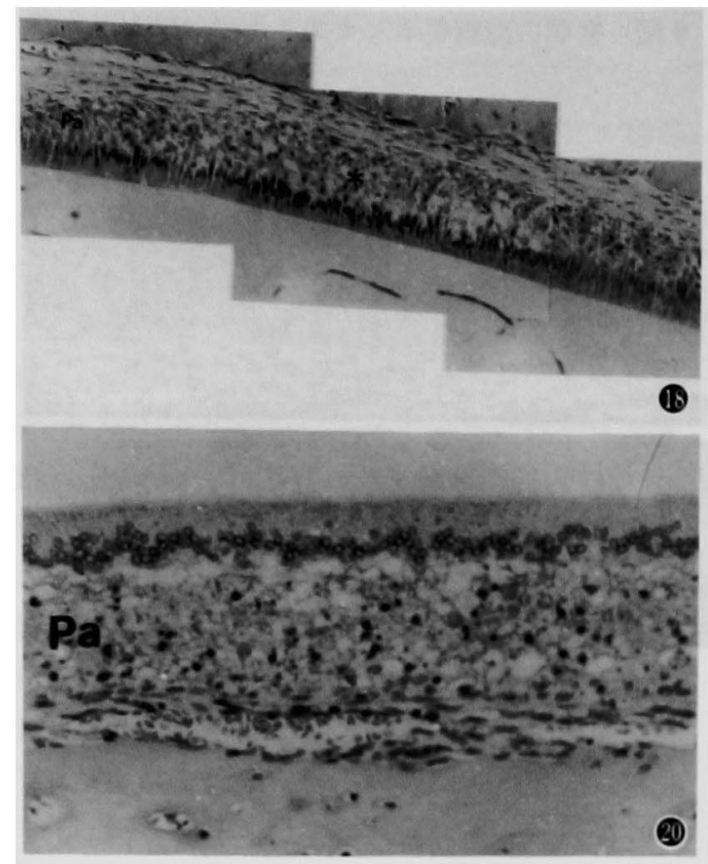

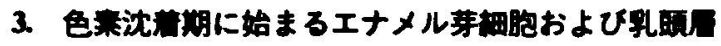

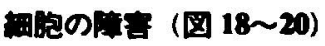

ある種のセフェム系抗生物實の大量 (3000 mg/ $\mathrm{kg} / \mathrm{day})$ を 5 週命の倠雄ラットに5 週間経口投与 すると，肉眼的には投蒀 4 週以降に上額および下 碩切歯に横紤状の白色变色巣が吐現した。病理組 学的には,色来沈着期に最初の変化がみられた。 この時期の頭周練胞は变性・壤死を呈し，乳頭 目の椎策は乱れ、それらの周囲には多数の鉄反応 阳性の頼䢂が散在していた。また，近接するエナ メル芽編胞の萎縮と铁色素を保有したエナメル芽 细胞の乳頭局への埋没が照められた。これらの变 化は販頭同細胞の障害が先行し，次いでエナメル 芽細胞の鉄色来分站陪守が生じたことを示してい ると考えられる。乳頭同細胞はエナメル芽細胞と 終末毛細血管との間の物空㻌送あるいは絴胞外物 䨘の吸収等に関連すると考えられているが，その 本想については不明である25。しかし、エナメル車 細胞が成㷛に伴って形䈍変化を示すと同時に，支 持組織ともいうべき乳頭首細胞もそれに伴って変 化することから, 両細胞間にはエナメル䔬形成に おいて密接な関連のあることが同われる。なお，拜 頭層細胞の萎縮はビタミンA 欠乏ラットてもみ られているが，その意䍳については不明である26。

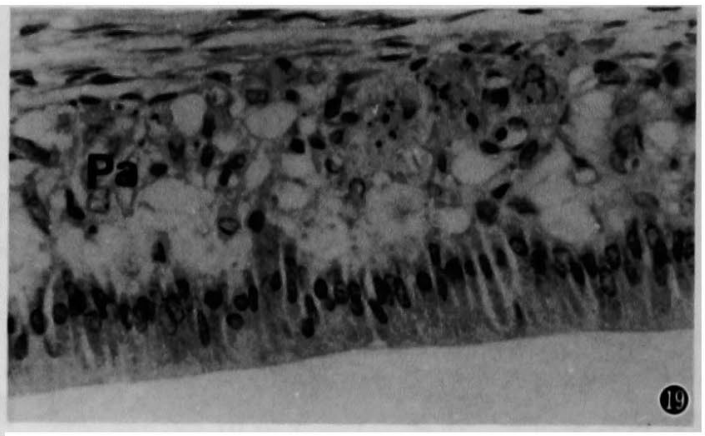

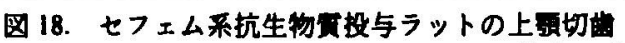

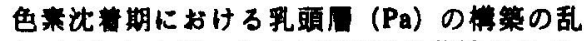

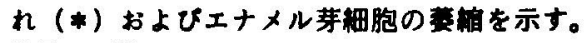
H.E., $\times 78$

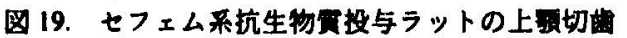

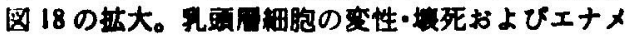
ル芽湅胞の茦缩を示す。

$P a:$ 献有. HE., $\times 312$

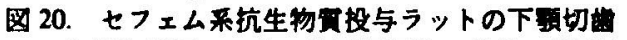

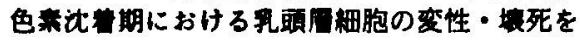
示す。

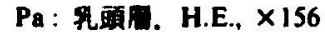

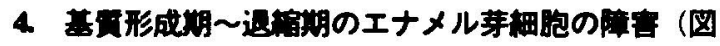 21 24)}

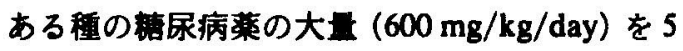
週部の雄雄ラットに 26 遇間経口投与すると,肉眼 的には投薬 17 週以降に下預切歯の表面に白色変 色巣が発現し，エナメル䨘表四の刻離，および切 告先端部の破損もみられた。これらの肉眼的変化 の推移には個体差があり，経時的に変化が増強す ろ例もあり，また回復する例もみられた。病理組 織学的には，变化は基䆩形成期から発現し，エナ メル芽練胞の変性と異常なエナメル基筫の分泌お よび色来沈着障客が広筙囲にわたって強くみられ た。エナメル芽湅胞は眍列不整で，接する乳頭展 には陥入したエナメル芽細胞およびマクロファー ジの集簇が㑇められた。退縮期においては，鉄色 莱を保有するエナメル芽細胞が齿肉首に埋没して みられた。肉眼的変化は, 実験の後期 (17 週以降) に強度の削㜔と闺連して発現しており，動物の強 度の代䣢害が全域のエナメル芽細胞の成熟過程 を障害したものと考えられる。

以上, 4 種類の萝威投与によろラット切齿の病 変分布を表 2 に示す。 


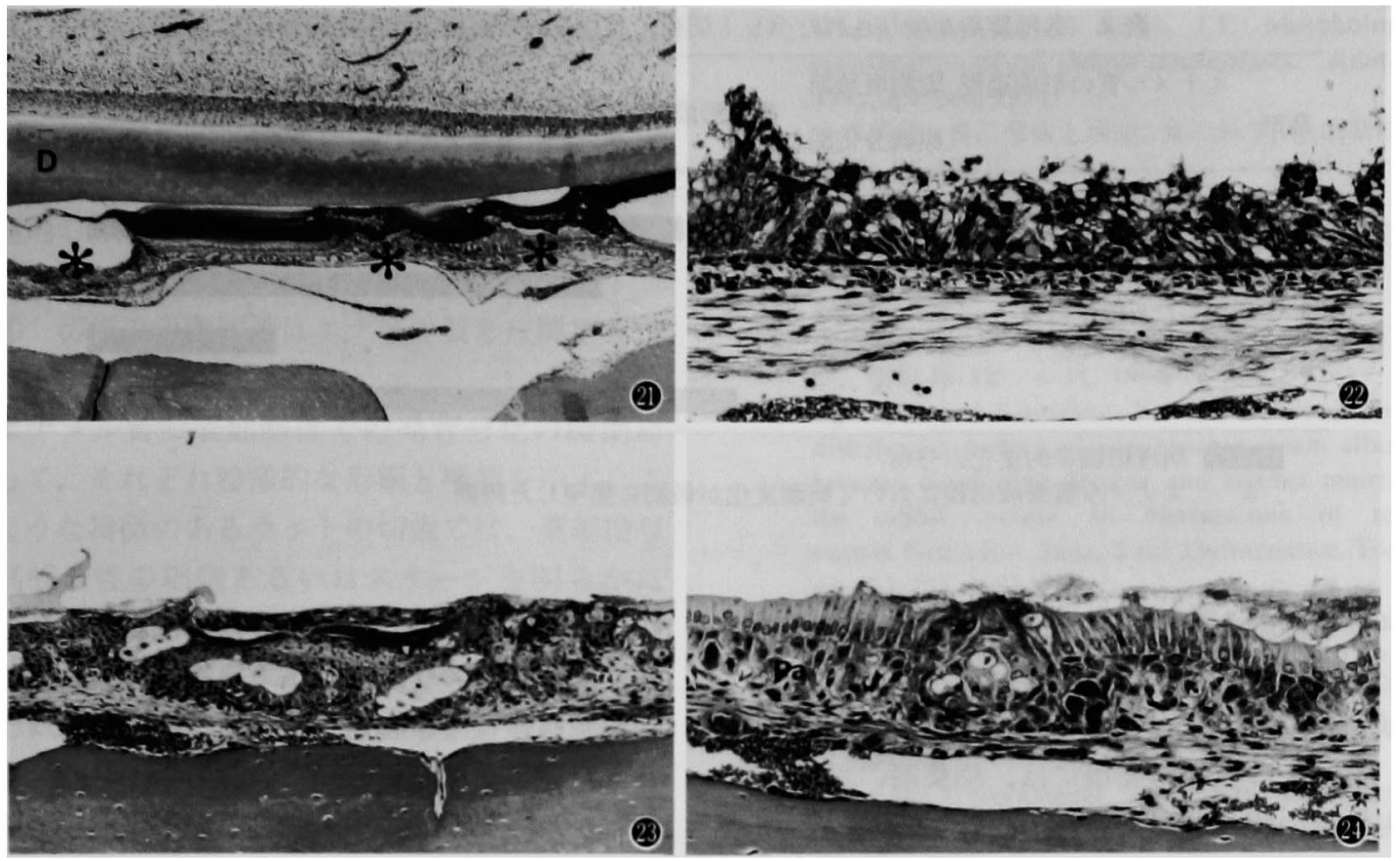

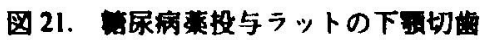

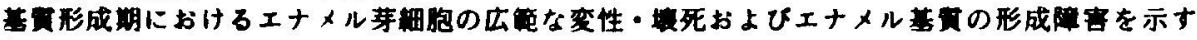
(*)。H.E., $\times 32$

图 22. 的展病菜投与ラットの下活切齿

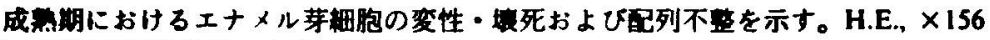

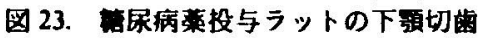

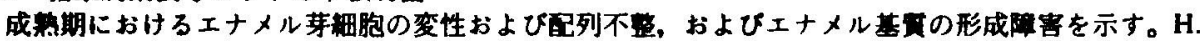
E., $\times 78$

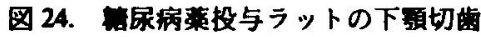

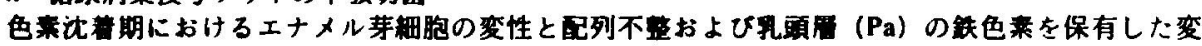
性エナメル芽姆胞およびマクロファージの集筷を示す。H.E., ×156

\section{考察およひまとめ}

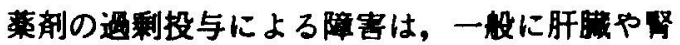
获のような软組織の器官に多く発現することが知 られているが，歯牙のように蒛根が完成し，萠出

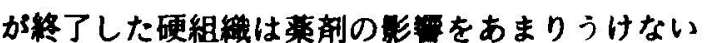
といわれている27。一方，歯牙はその形成期におい て全身的あるいは局所的な種々の因子の影歶をう けた場合には形成異常をきたす。全身的因子とし ては各種栄素索の欠乏, ホルモンの異常, その他 の全身的疾患，フッ素の過剩摄取などがあり，局 所的因子としては歯胚におよほす外但，炎症，放 射線の作用がある ${ }^{1,6.26}$ 。ラットの切菌は終生成長 し続けることから，末分化の細胞から成熟した細 胞まで各発育段階の細胞が配列しており，薬剂の
影掣をうけた場合は画牙の形成が阻害されて各種 の病理変化を招来する。エナメル宙の形成障害の 原因となり得るものは多彩であり，各種の薬剤に よる実検的齿牙形成障害に関する報告は多い。

フッ来化合物はヒトの刻状齿をもたらすことで 知られているが、ラットでは基質形成期エナメル 芽細胞の分䎵を障害し，異常基質を形成するだけ でなく，成熟期のエナメル芽細胞にも賃害を与え， 水分や有機性基筫の脱却を障害することにより二 次石灰化にも異常を招来する22,28,29。

画牙に現れる病変との因果関係が明らかにされ ている抗生物質にはテトラサイクリンおよび ピューロマイシンがある。テトラサイクリンを新 生児に投与すると黄色雪と形成不全歯の発生する ことが知られているが，ラットでは基赛形成期エ 


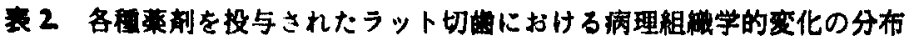

\begin{tabular}{|c|c|c|c|c|}
\hline エ+メル目の形成過程 & & 基晋形成期 & 成 栔 & \\
\hline 柬削 & 細螎分化期 & 移行期 & （形恋变化）色来沈社期 & 退樎期 \\
\hline I. フルオロウラシル酶体 & & b & & \\
\hline 2. アクロライド香抗生物而 & & $\$$ & & \\
\hline 3. 七フェム系抗生物貫 & & & $\$$ & \\
\hline 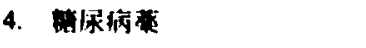 & & 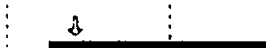 & & \\
\hline
\end{tabular}

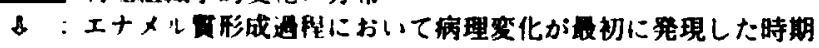

ナメル芽細胞に㜔を与え、エナメル實の形成不 全をもたらす30。まだピューロマイシンもラット の基算形成期のエナメル芽紻胞に㜔要を与える か，これらの変化の発現には，㞹莱詴の曐白合成 阻害作用の関与が示钱されている゙!。

ストロンチウム(Sr) itラットつ基形成胡エ+ メル芽細胞の空胞化扩よび成热期エナメル芽細胞 の春樎、配列つ乱れ、萧胞形成な上゙を引き起こす。

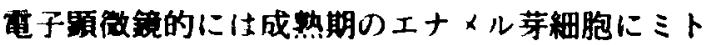
コンドリアの然化・空胞化がみられることから，Sr 投与に上って、同锞胞のエネッギー代謝に障害が 起こり。云れが細胞い吸收能やCa移送能を阻害 し.エナメル質の成整に障害を与えると考えられ こいる32。

做小管阻害威でちるコルヒチン，ビンフラスチ ンおよジピンクリスチンな上゙はラットの基嘪形成 期工十メル芽細胞汇对して注，細胞骨格系の維持

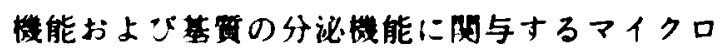
チュフルを阻:"゙し，䒠た，成然期エナメル牙細胞

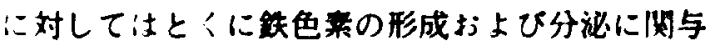
ナるマイフロチュブル阻書し、エナメル贯の形 成障害と色来沈着隔赛を引き起こす33.34。

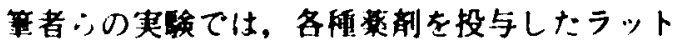
の切歯に洁共通して肉眼的方白色変色果が発現 し、これらの変化は切茵が磨耗によって消失する まで長期にわたって䚑察することがてた。病理 組織学的にはエナメル牙紐胞の変性・壤死, 同細 胞居の配列不整と其胞形成，エ十メル基筫の異常 今産生, 鉄色素沈着障害, 乳頭層細胞の変性・壤 死お上ひエナメル質の低石灰化展なよ゙が認められ た。エナメル筫形成過程における病変の発現開始
は基界形成期，移行期および色采沈音期と，各薬 刺で異なっており，また，障書をうけたエナメル 芽㪴胞は信得せずに経過する傾向が認められた。 各蔧詴投与により病変の発現開始時期に差異が あったが，取終的には共通して色索沈蒠障害が認 めうれることから，本所見はエナメル䨘形成過程 の障害を反映する跘敏な指標になると考えられ る。

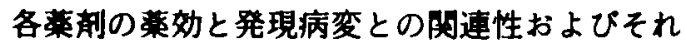
ぞれの病変の発現機序については不明な点が多 い。しかし，エナメル芽細胞を障害する因子とし ては、先に述へたように蛋白合成阻害, エネルギー 代䜊障害，殿小管阻害などの作用が考えられる。ま

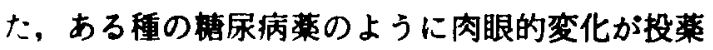
17 週以降に強度の削瘦と成連して荤延性に発現 する場合は，代辢障害などの全身的原因による可 能性も考えられる。

然牙の毒性に関する報告は多いが，発生病理に 网しては不明な点が多い。しかし、ラットの切蒾 はその檍造上の特徽から，他の諸䑏器にみられな い以下の特期をもっており, 毒性病理学的分野に おける有用性は高いといえる。

(1) 一本の切齿の綎断面でエナメル䨘形成の細 胞增殖期から退樎期に至る全過程の同時観察が可 能である。また，薬戍に対して高感受性の細胞お よびその stage, 病変の経時的推移およびその回復 性を比较的容易に覞察することができる。

(2) 形成が終了し，萌出した宷牙には血流を介 した薬冎による毒性変化は発現しない。したがっ て，一旦エナメル贸に出現した変化は磨耗によっ て消失するまで脣期にわたる肉眼的観察が可能で 


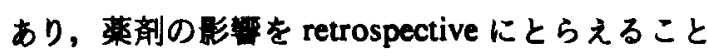
がでる。

(3) 薬片の初回投与から，切曾の肉眼的変化が 無現するまての時間的経過を検索することによっ て菜郕の標的時期（target stage）を予测すること ができる

(4) 切菌の色来沈着はエナメル賽形成障害を反 映する鋭敏な指檽となる。

エナメル貫形成細胞はその発育分化の時期に よってそれそれ特徽的な形隹と機能を示す。こ のような特徵のあるラットの切雪では，薬戍投与 に高感受性の細胞あるいはステージを明らかに し，とくにエナメル貫形成過程における標的時期 (traget stage) を特定することは毒性発現機序を知 ろ上て重要てある。今回は微細形態学的模案は実 施していないか，このような技術を併用すること によって初期病変や回復性の詳細を明らかにし。 切齔における桧合的な毒性病理を解明することが 必要てあろう。

\section{女 㰴}

1. Barker, IK and Van Dreumel, AA : The alimentary system. In : Pathology of domestic animals, Vol 2, Jubb, KVF, et al Eds, Academic Press, New York, pp. 1-11, 1985.

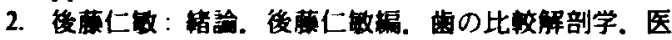

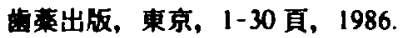

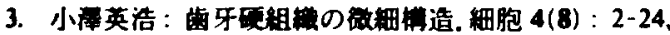
1972.

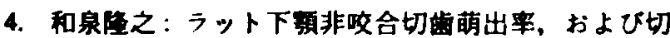
版組成に及はす1-Hydroxy-ethylidene-1,1-

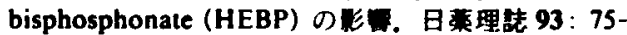
87, 1989.

5. Robinson, C, Kirkham, J, and Nutman, CA : Relationship between enamel formation and eruption rate in rat mandibular incisors. Cell Tissue Res 254: 655-658, 1988.

6. Schour, I and Massler, $M$ : The teeth. In : The Rat in Laboratory Invesigation, ET Farris and JQ Griffith Ed, JB Lippincott Co., Philadelphia pp. 104-165, 1963.

7. Halse, $A$ : Location and first appearance of rat incisor pigmentation. Scand J Dent Res 80 : 428-433, 1972.

8. Lindemann, $\mathbf{G}$ : Rat incisor pigmentation. Tandlaegebladet $74: 662-670,1970$.

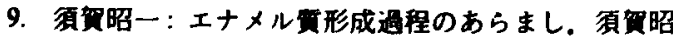

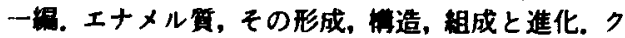
インテッセンス出版佅式会社, 東京, 46-49 頁, 1987.

10. Leblond, CP and Warshawsky, H : Dynamics of enamel formation in the rat incisor tooth. J Dent Res 58(B) : 950-975, 1979.
11. Warshawsky, $\mathrm{H}$ and Smith, CE : Morphological classification of rat incisor ameloblasts. Anat Rec 179: 423-446, 1974.

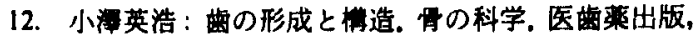
東京, 76-109 頁, 1985.

13. 佐々木整：エナメル基算の生化学ーアメロゲニンと

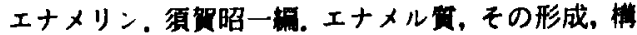
造, 粗成と進化.クインテッセンス出版, 東京, 153162 頁, 1987.

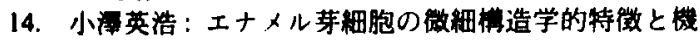
能. 湅胞 16(12)：6-11， 1984.

15. Ogura, $\mathbf{H}$ and Kinoshita, $Y$ : The difference in the distribution pattern of administered serum albumin between developing dentine and enamel matrix in the rabbit incisor. In: Mechanisms of tooth enamel formation, Suga, S Ed, Quintessence, Tokyo, pp. 143-154, 1983.

16. Smith, CE and Warshawsky, $H$ : Quantitative analysis of cell turnover in the enamel organ of the rat incisor : evidence for ameloblast death immediately after enamel matrix secretion. Anat Rec 187: 6397. 1977.

17. Moe, H: Physiological cell death of secretory ameloblasts in the ral incisor. Cell Tissue Res 197 : 443-451, 1979.

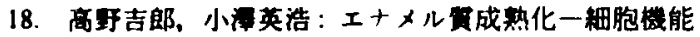

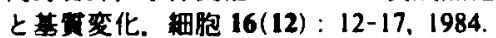

19. McKee, MD, Zerounian, C, Martineau-doize, B, and Warshawsky, $H$ : Specific binding sites for transferrin on ameloblasts of the enamel maturation zone in the rat incisor. Anat Rec 218 : 123-127, 1987.

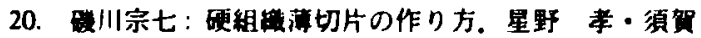

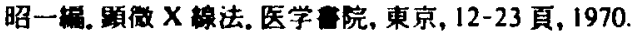

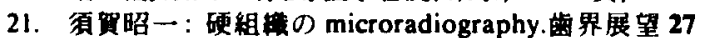
(4) : 495-515, 1966.

22. 石田 武：急性フッ菜中䓯庭におけるエナメル负形

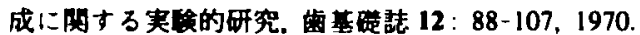

23. Abe, T, Masuoka, $M$, Nomura, $M$, and Miyajuma, $H$ : Effects of fluoride on developing enamel and dentin of rat incisors. fluoride Research 1985, Stud Environ Sci 27 : 299-305, 1986

24. Reith, EJ : The stages of amelogenesis as observed in molar teeth of young rats. Ultrastr Res 30 : 111 151, 1970.

25. 得昭一：齔の細胞一特にエナメル西の形成，小川 和朗，用住一昌，小池㕵淳，佐藤正一編. 趿物細胞 学 I. 朝合告店, 菓京, 15-46 頁, 1977.

26. Pindborg. JJ : Pathology of the Dental Hard Tissues. W. B. Saunders, Philadelphia. pp. 138-210, 1970.

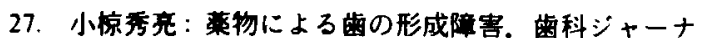
ル 17(6): 797-807, 1983.

28. 伊集院直邦：急性フッ菜中海症におけるエナメル買

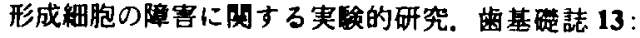
39-61, 1971.

29. 長谷川清：怚性フッ来中毒症におけるエナメル留形

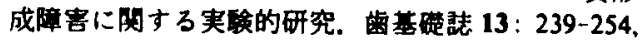
1971.

30. Westergaard, J : Structural changes induced by tetracycline in secretory ameloblasts in young rats. Scand J Dent Res 88 : 481-495, 1980. 
31. Weinstock, A : Cytotoxic effects of puromycin on the golgi apparatus of pancreatic acinar cells, hepatocytes and ameloblasts. J Histochem Cytochem 18 : 875-886, 1970.

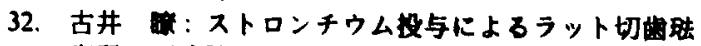

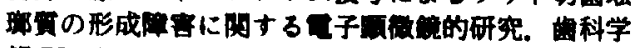
䇉 77 : 847-879, 1977.
33. Hashimoto, $\mathrm{K}$ : The effect of colchicine on the pigmentation of the enamel surface in rat incisors. Bull Tokyo Med Dent Univ 31 : 115-126, 1984.

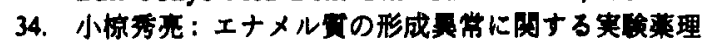

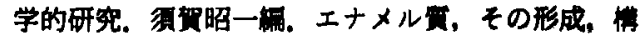
造, 組成と進化.クインテッセンス出版, 東京, 324337 桼, 1987. 